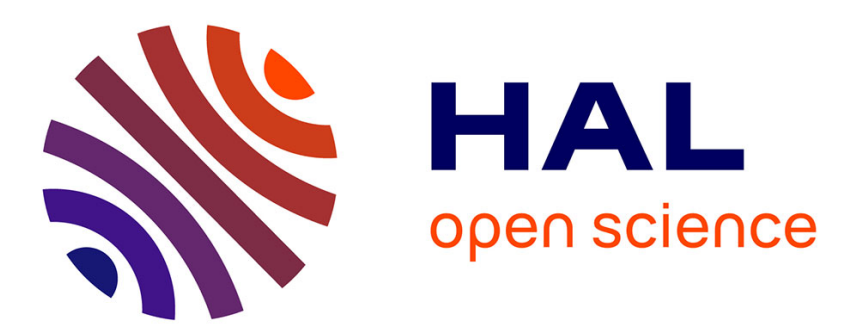

\title{
Laboratory scale study of an industrial phosphate and thermal treatment for polluted dredged sediments
} Souhila Kribi, Jocelyn Ramaroson, Ange Nzihou, Patrick Sharrock, Guy

Depelsenaire

\section{- To cite this version:}

Souhila Kribi, Jocelyn Ramaroson, Ange Nzihou, Patrick Sharrock, Guy Depelsenaire. Laboratory scale study of an industrial phosphate and thermal treatment for polluted dredged sediments. International Journal of Sediment Research, 2012, 27 (4), p. 538-546. 10.1016/S1001-6279(13)60011-6 . hal-01632403

\section{HAL Id: hal-01632403 https://hal.science/hal-01632403}

Submitted on 6 Nov 2019

HAL is a multi-disciplinary open access archive for the deposit and dissemination of scientific research documents, whether they are published or not. The documents may come from teaching and research institutions in France or abroad, or from public or private research centers.
L'archive ouverte pluridisciplinaire HAL, est destinée au dépôt et à la diffusion de documents scientifiques de niveau recherche, publiés ou non, émanant des établissements d'enseignement et de recherche français ou étrangers, des laboratoires publics ou privés. 


\title{
Laboratory scale study of an industrial phosphate and thermal treatment for polluted dredged sediments
}

\author{
Souhila KRIBI ${ }^{1}$, Jocelyn RAMAROSON ${ }^{1}$, Ange NZIHOU ${ }^{1}$, \\ Patrick SHARROCK ${ }^{2}$, and Guy DEPELSENAIRE ${ }^{3}$
}

\begin{abstract}
Dredged sediments are being chemically treated with phosphoric acid on an industrial scale. The effectiveness of the treatment was evaluated by performing the chemical reaction in a tubular reactor, followed by convective drying and maturation of the treated sediment at ambient temperature and finally thermal destruction of the organic matter by calcinations $\left(500^{\circ} \mathrm{C}-900^{\circ} \mathrm{C}\right)$. The influence of acid concentration and calcination temperature on the specific surface area of the sediment was investigated. The stabilization of the heavy metals was evaluated by leaching tests and sequential extraction procedures. The phosphoric acid treatment is effective in reducing heavy metal mobility, a prerequisite for recycling the sediments in various construction materials.
\end{abstract}

Key Words: Dredged sediments, Heavy metal pollution, Chemical treatment, Thermal treatment

\section{Introduction}

Phosphoric acid treatment of contaminated dredged sediments is one way to minimize the adverse effects of pollution (Rulkens, 2005; Hettiarachchi and Pierzynsky, 2006). Sediments in waterways and seaports are most likely to suffer from anthropogenic pollution (Mulligan et al., 2001). They also represent the class of sediments local authorities must deal with to maintain ecological function, leisure and commercial navigation.

Dredging such sediments and transporting them to landfills raises concerns on short-term and long-term environmental impacts. Remediation technologies were developed in order to stabilize contaminated soil (McGowen et al., 2001; Zwonitzer et al., 2003; Raicevic et al., 2005; Arnich et al., 2003; Basta and McGowen, 2004) but may not apply to excavated water-laden sediments containing large amounts of organics and heavy metal ions. The leaching of dredged sediments deposited on-land has the potential to mobilize many toxic elements (Stephens et al., 2001; Caetano 2003). Aerobic oxidation of contaminants previously found in underwater reduced forms such as sulfides may increase the dissolution of heavy metal sulfate species. Previous investigations have confirmed that heavy metals are present in potentially available fractions such as exchangeable, adsorbed or organically bound species, presumably more harmful, which can contaminate plants, grazing animals and run-off waters (Chen et al., 2006).

The industrial scale phosphoric acid treatment of dredged sediment was developed in order to provide a cost effective process well adapted to avoid formation of waste residues. The first step involves mixing in some phosphoric acid by pumping it simultaneously with the dredged suspension through a static reactor.

\footnotetext{
${ }^{1}$ Ph.D., Ecole des Mines d'Albi-Carmaux, RAPSODEE UMR-CNRS 2392, Route de Teillet-81013 ALBI CT Cedex 09, France

${ }^{2}$ Paul Sabatier University, LERISM, 31062 Toulouse, France, E-mail: Patrick.sharrock@gmail.com; Patrick.sharrock@free.fr

${ }^{3}$ Solvay, DCRT, Rue de Ransbeek 310, Brussels, Belgium
} 
Following foaming, the treated sediment is air-dried. A second step is proposed which consists in a thermal treatment to remove all organic matter by combustion. Both processes impact on heavy metal properties (Bournonville et al., 2006, 2004; Piantone et al., 2003). We describe here the behaviour of heavy metals and discuss how the physicochemical treatment selectively transforms the distribution of metals from the more available fractions to the more inert residual fraction. This treatment process allows opportunities for the safe valorisation of treated sediments as road base and in embankments and construction materials. The beneficial reuse of such dredged solids has the potential to offset the added cost of treatment. Solvay is now implementing a phosphoric acid treatment known as the Novosol process to treat dredged sediments from Venice in Italy. We report here results obtained at the laboratory scale with river sediments treated in a similar fashion.

Several waterways in use connect northern France with the sea in Holland via Belgium. Due to local government restrictions edicted in 1995, polluted dredged sediments can no longer be dumped at sea or spread on land without prior treatment. Figure 1 illustrates the main waterways going from Charleroi to Antwerpen via a canal through Brussel or via the Meuse river through Namur and Liège.

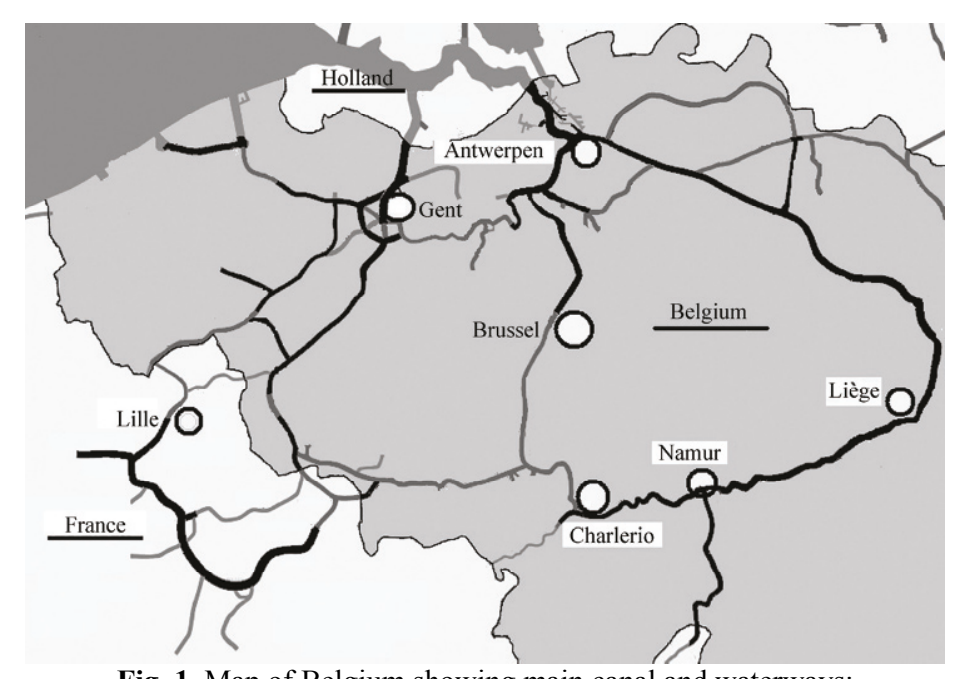

Fig. 1 Map of Belgium showing main canal and waterways In blue with $5 \mathrm{~m}$ depth, and in dark with $7.5 \mathrm{~m}$ depth

River through Namur and Liège. An estimated 1,500,000 $\mathrm{m}^{3}$ of sediments remain to be dredged due to accumulation during the past ten years when dredging operations were stalled because $70 \%$ of the sediments were classified as contaminated. An experimental center was implemented adjacent to the Sambre River located at Farciennes near Charleroi. The site occupies $30,000 \mathrm{~m}^{2}$ and can store $6,000 \mathrm{~m}^{3}$ of dredged sediments in a sealed zone. As shown in Fig. 2, the Sambre meanders from Charleroi to reach the Meuse in Liège. The immediate environment is composed of farmland, dispersed forests or parks and industrialized and inhabited areas. The Charleroi region was one of the major metallurgical centers of Eastern Europe and industrial activites started early in the $19^{\text {th }}$ century. There were more than a hundred interconnected small rivers in this Wallone region, many of them now being covered with mine wastes and tailings.

\section{Experimental}

Sediments originating from the Farciennes site in Belgium were collected in closed plastic containers and stored at $4^{\circ} \mathrm{C}$ before the experiments. Major elements present were (in $\mathrm{mg} \mathrm{kg}^{-1}$ dry matter): $\mathrm{Al}$ (52400), $\mathrm{Fe}$ (32975), Ca (27345) and minor elements were: As (164), Cd (4), Cr (191), Cu (143), P (2192), Pb (214) and $\mathrm{Zn}$ (1004). The sediment water content was $52 \%$, the conductivity was $1.6 \mathrm{mS}$, the pH 7.2 and the cation exchange capacity was $30 \mathrm{meq} 100 \mathrm{~g}^{-1}$. Powder X-ray diffraction patterns indicated the presence of quartz, calcite and feldspar. An experimental reactor was set up (Fig. 3) which consists of a thermo regulated glass tube of $110 \mathrm{~cm}^{3}$ volume. The reactor was connected to two peristaltic pumps to precisely regulate the flow 
rates up to $400 \mathrm{~g} \mathrm{~min}^{-1}$. The first pump supplied a steady amount of raw sediment; the second pump fed $85 \%$ phosphoric acid in the desired proportions. The sediments were treated with phosphoric acid in quantities of $3 \%, 5 \%$ and $7 \%$ by weight of the sediment dry mass. The treated sediments collected at the outlet were then air-dried and calcined. The calcinations were carried out in an Aubry furnace of $2 \mathrm{~L}$ capacity. The calcinations were carried out with $2 \pm 0.5 \mathrm{~g}$ of sediment dried in cylindrical alumina crucibles $1.5 \mathrm{~cm}$ in diameter and $2 \mathrm{~cm}$ height. The raw as well as the treated sediments were calcined for three hours at 300,500 , 700,900 and $1,100^{\circ} \mathrm{C}$ with heating at a rate of $10^{\circ} \mathrm{C} \mathrm{min}^{-1}$.

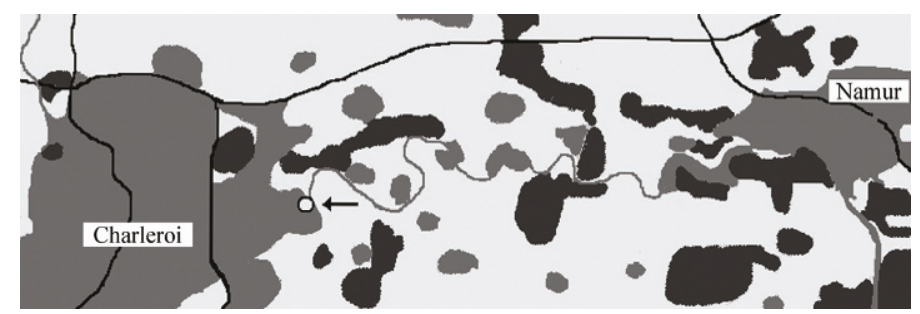

Fig. 2 Map showing the site of Farciennes (arrow) where the sediments were dredged. The dark areas are industrial or inhabited, the light areas are farmland and the light gray areas are forests or parks

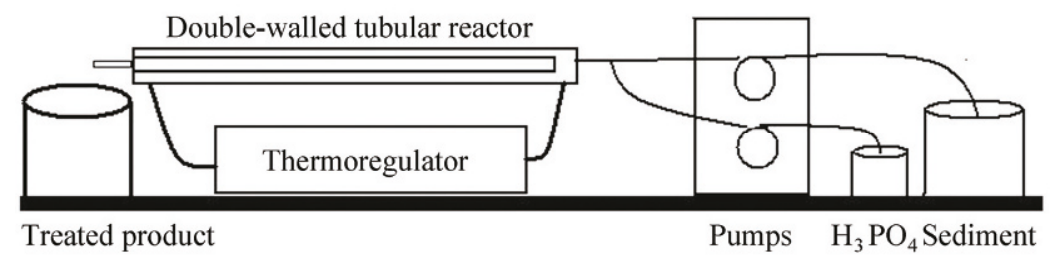

Fig. 3 Experimental set up for the phosphoric acid treatment of sediments.

The temperature was maintained at $298 \mathrm{~K}$

A sequential extraction test was carried out in order to evaluate the fate of the metal ions (mobility, speciation) before and after the chemical treatment and before and after calcination. Using the method proposed by Tessier, (Tessier et al., 1979) the metals present in the sediments were divided into five parts and labelled as: exchangeable (F1), carbonate bound (F2), manganese and iron oxides bound (F3), complexed with organic matter and sulfides (F4), and residual metals (F5). Extractable fractions of metals in river sediments have been reported (Li et al., 2009).

Filtrates derived from sequential extractions were analysed by Inductively Coupled Plasma Spectroscopy (ICP) with an overall error due to extraction and analysis estimated at 5\%. The physical properties of the raw and treated sediments were followed by measurements of true density by gas pycnometry with a Micromeritics Acupic 1330 using helium. The specific surface areas were measured with nitrogen adsorption by the BET method using a Micromeritics Gemini instrument.

\section{Results and discussion}

As phosphoric acid was pumped into the sediment, a chemical reaction occurred with immediate release of gas. Analysis of the gas indicated the presence of carbon dioxide and dihydrogen sulphide. These emissions were due to acid reactions between metal carbonates, sulphides, and organic matter. The reactions lead to the formation of foam which modified the structure of the sediment. A linear relationship was found between the volume of gas evolved and the quantity of acid, with $280 \mathrm{mmoles}$ of $\mathrm{CO}_{2}$ released for 320 mmoles of acid added. This clearly indicates that most of the phosphoric acid reacted with carbonates, particularly calcium carbonate identified in the sediments. Some acid also reacted with metal sulfides, releasing hydrogen sulphide and metal ions. The heavy metals arise from past industrial activity elated to metallurgy in this area. Tracers can be used to estimate sediment sources (Juracek and Ziegler, 2009). This reaction is expected to produce calcium phosphate precipitates which also co-precipitate divalent heavy metals (Melamed et al., 2003; Sugiyama et al., 2002). The viscosity of the suspension decreased regularly with addition of acid, from $400 \mathrm{mPa}$.s for untreated sediment to $200 \mathrm{mPa}$.s for the sediment with $7 \%$ phosphoric acid. One minute after acid introduction, the $\mathrm{pH}$ declined from 5.3 to 4.8 for 
$3 \%$ and $7 \%$ acid, respectively. Twenty minutes later, the $\mathrm{pH}$ values were 5.9 and 5.1 . The $\mathrm{pH}$ continued to rise slowly thereafter, reaching 6.5 and 6.1 after three days. Final pH stabilized to between 7.0 and 6.7 following a maturation period of 600 hours. This shows the acid was consumed and slowly neutralized at room temperature as illustrated in Fig.4.

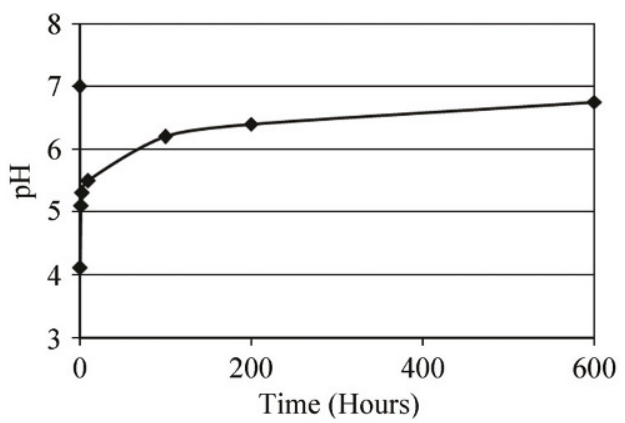

Fig. 4 Evolution of $\mathrm{pH}$ with time following $7 \%$ phosphoric acid addition to sediments

Specific surface areas of the different sediments after drying (Fig. 5) showed a notable evolution with an initial $4.5 \mathrm{~m} \mathrm{~g}^{-1}$ for the raw sediment to $14.2 \mathrm{~m}^{2} \mathrm{~g}^{-1}$ for the sediment treated with $7 \%$ phosphoric acid. This was accompanied by a small reduction in the measured density, from $2.49 \mathrm{~g} \mathrm{ml}^{-1}$ to $2.47 \mathrm{~g} \mathrm{ml}^{-1}$. These variations in the structure of the sediment are the consequence of gas evolution forming vesicles and creating microporosity. The larger surface areas explain the reduced drying times observed for treated sediments

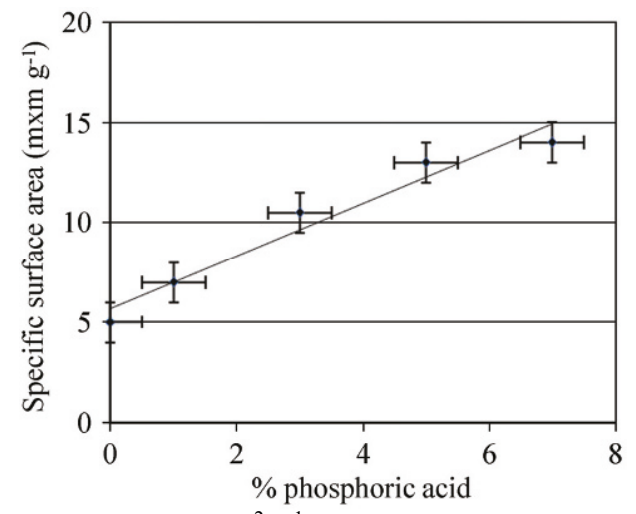

Fig. 5 Specific surface areas $\left(\mathrm{m}^{2} \mathrm{~g}^{-1}\right)$ of the air dried sediments as a function of the percentages of added $85 \%$ phosphoric acid

To further highlight the structural changes in the sediment, samples were calcined at various temperatures. Results presented in Fig. 6 show that the specific surface areas tripled on the average for treated or untreated sediments upon calcinations, up to temperatures near $500^{\circ} \mathrm{C}$. This is related to the removal of the organic phase and the exposure of newly formed interconnected porosity. After organic matter was consumed above $600^{\circ} \mathrm{C}$, the surface areas decreased dramatically due to sintering of the minerals. The addition of phosphoric acid to the sediments systematically expanded surface areas up to temperatures near $700^{\circ} \mathrm{C}$.

A $10 \%$ increase in density was observed up to a temperature of $700^{\circ} \mathrm{C}$, reaching a maximum of $2.68 \mathrm{~g} \mathrm{~cm}^{-3}$. Bulk density was reduced to $2.65 \mathrm{~g} \mathrm{~cm}^{-3}$ upon calcination at $1,100^{\circ} \mathrm{C}$. This change can be attributed largely to the combustion of the organic matter present at levels of $5 \%$ of the dry weight and which left behind heavier minerals. Some sintering or consolidation of agglomerates may also occur. Above $800^{\circ} \mathrm{C}$, decomposition of residual carbonates or dehydroxylation of clays may create and trap some porosity. 


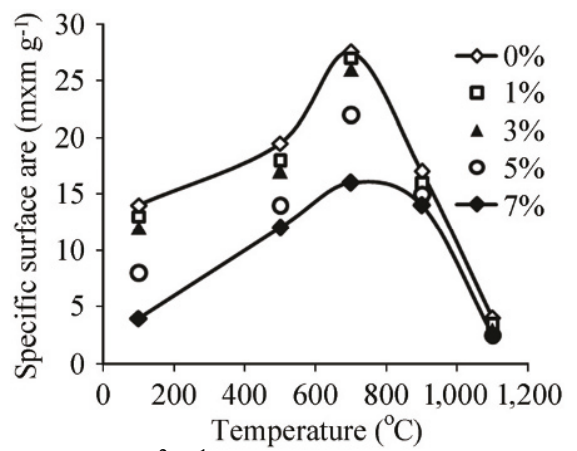

Fig. 6 Specific surface areas (SSA) in $\mathrm{m}^{2} \mathrm{~g}^{-1}$ for the sediments as a function of treatment temperatures. The various percentages of added $85 \%$ phosphoric acid are indicated with different symbols

To evaluate the effects of chemical and thermal treatments, leaching tests were conducted to evaluate metal release. Dissolution in distilled water with a solid/liquid ratio of $1 / 10$ revealed the importance of heavy metal leaching in the untreated samples, with $\mathrm{Pb}$ and $\mathrm{Zn}$ all above $2 \mathrm{mg} \mathrm{L}^{-1}$. The results are presented in Table 1.

Table 1 Solubility tests in water according to NF X30-402-2. Concentrations of the elements are in $\mathrm{mg} \mathrm{kg}^{-1}$ dry matter. The percentages of $85 \%$ phosphoric acid added are indicated as well as the treatment temperature. RT is room temperature

\begin{tabular}{|c|c|c|c|c|}
\hline & $\mathrm{Cr}$ & $\mathrm{Cu}$ & $\mathrm{Pb}$ & $\mathrm{Zn}$ \\
\hline $\mathrm{O} \% \mathrm{RT}$ & $<0.001$ & 2.0 & 2.2 & 2.6 \\
\hline $3 \% \mathrm{RT}$ & $<0.001$ & $<0.001$ & $<0.003$ & 0.7 \\
\hline $7 \% \mathrm{RT}$ & $<0.001$ & $<0.001$ & $<0.003$ & 1.5 \\
\hline $0 \% 700^{\circ} \mathrm{C}$ & 10.4 & $<0.001$ & $<0.003$ & 1.7 \\
\hline $3 \% 700^{\circ} \mathrm{C}$ & 9.1 & $<0.001$ & $<0.003$ & 0.5 \\
\hline $7 \% 700^{\circ} \mathrm{C}$ & 7.0 & $<0.001$ & $<0.003$ & 0.6 \\
\hline
\end{tabular}

Calcinations with no acid added decreased the concentrations of leached metals but increased Cr solubility to above $10 \mathrm{mg} \mathrm{L}^{-1}$. This can be explained by the oxidation of this metal to more soluble $\mathrm{Cr}^{6}+\mathrm{species}$. The chemical treatment with 3\% phosphoric acid remarkably reduced the solubility of all metals investigated. $\mathrm{Zn}$ solubilities behaved differently and only decreased from 2.6 to $0.7 \mathrm{ppm}$. Leachable $\mathrm{Zn}$ increased to 1.5 $\mathrm{mg} \mathrm{L}^{-1}$ with $7 \%$ phosphoric acid, indicating this metal was sensitive to $\mathrm{pH}$ and had less affinity for insoluble phosphate formation than the other metals. However, calcination to $700^{\circ} \mathrm{C}$ reduced the solubility of zinc to $0.5 \mathrm{mg} \mathrm{L}^{-1}$ and also reduced that of $\mathrm{Cr}$ significantly. To further analyse the behaviour of heavy metals in the treated sediments, the distribution of selected elements were determined according to the Tessier procedure.

Figure 7(a) illustrates the phosphate concentrations measured in the five fractions (Where F1 is exchangeable, F2 carbonate bound, F3 Fe and Mn oxydes bound, F4 organic and sulfide bound and F5 residual) for the untreated and treated sediments, and with the subscript $\mathrm{c}$ (F1c...) for the same samples calcined at $700^{\circ} \mathrm{C}$.

The small amount of phosphate originally present in the sediment was located in fractions 3,4 and 5 . Following simple calcination, there was no notable change. After the phosphate chemical treatment, $\mathrm{P}$ found in the first four fractions was in larger amounts than in F5. Phosphates were therefore precipitated in the solid phase but the phosphates formed were relatively easy to mobilise. However, after calcination, most of the phosphorous was contained in the most stable and insoluble F5 fraction with a trend proportional to the quantity of phosphoric acid used in the treatment. Calcination of freshly precipitated phosphate reaction products greatly impacted on crystallisation and stability of phosphate salts. Calcium orthophosphates are known to first form amorphous precipitates which then crystallize upon heating to produce more stable insoluble species. 

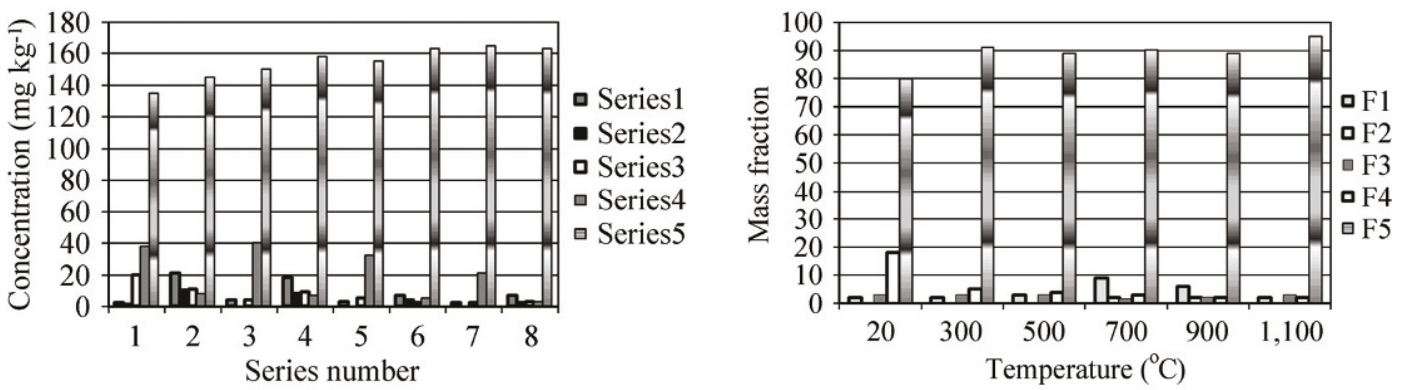

Fig. 7 (a) Influence of quantity of acid and thermal treatment $\left(700^{\circ} \mathrm{C}\right)$ on the speciation of phosphorus. (b) Influence of calcination temperature on the speciation of the phosphorus of a sediment treated with $5 \%$ phosphoric acid

Figure 7(b) further illustrates this trend as a function of temperature for the sediment treated with 5\% phosphoric acid. Calcination up to $700^{\circ} \mathrm{C}$ decreased the first fractions of $\mathrm{P}$ and formed stable $\mathrm{F} 5$ compounds which account for $90 \%$ of total $\mathrm{P}$. Beyond $700^{\circ} \mathrm{C}$, some residual phosphates (originally in F5) moved to other fractions (F4 and F3). Very high temperatures are therefore not necessary nor recommended to stabilize the metal phosphates formed.

Figure 8(a) presents the evolution of the percentages of $\mathrm{Ca}$ present in the 5 fractions as a function of calcination. In the raw sediment, $42.8 \%$ of the $\mathrm{Ca}$ was present as carbonate. Following calcinations, this carbonate decomposed to soluble calcium oxide present in fraction F1. Addition of phosphoric acid to the sediment also caused carbonate decomposition proportional to the amount of acid used (F2 decreases). The $\mathrm{Ca}$ was then distributed in other available forms (mostly F1) which could be related to the formation of relatively soluble calcium hydrogenphosphates. In this case, the result of calcination strongly depended on the excess calcium carbonate present which produced soluble lime. When more phosphoric acid was present, more stable residual calcium was present once the reaction products were calcined.
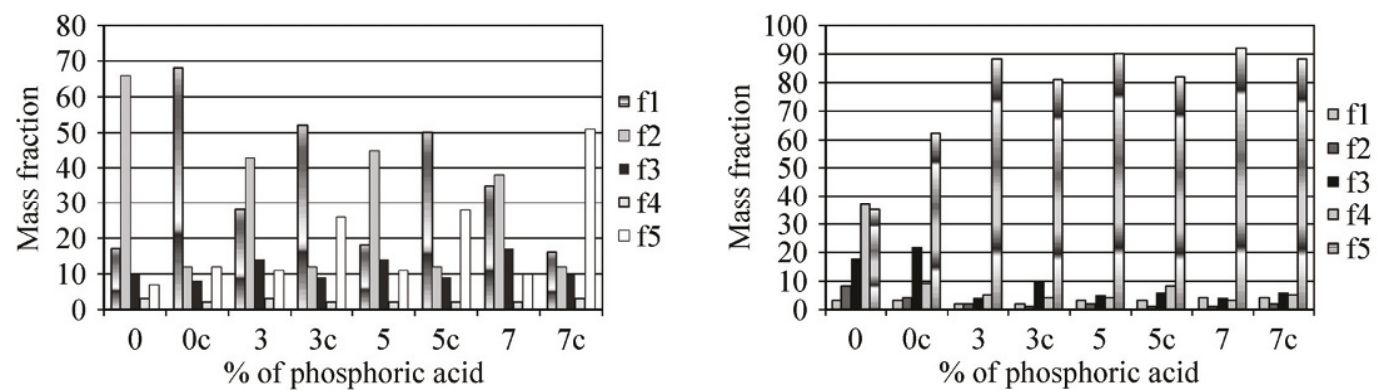

Fig. 8 Influence of quantity of acid and thermal treatment $\left(700^{\circ} \mathrm{C}\right)$ on the speciation of $\mathrm{Ca}$ (a, upper) and $\mathrm{Pb}(\mathrm{b}$, lower)

This is indicative of the formation of thermodynamically stable calcium phosphates of the apatite family with high $\mathrm{Ca} / \mathrm{P}$ atomic ratio (Srinivasan et al., 2006; Loannidis and Zouboulis, 2003; Theodoratos et al., 2002; Boisson e al., 1999; Cao et al., 2004).

Figure 8 (b) illustrates the distribution of species for $\mathrm{Pb}$. In the starting sediment, $18.4 \%$ of $\mathrm{Pb}$ was in fraction F3, 36\% in F4 and 33\% in F5. Simple calcination gave $62 \%$ insoluble $\mathrm{Pb}$ in F5c. This again demonstrated that thermal treatment alone can help immobilise metals. The remarkable impact of chemical treatment on lead stabilisation was seen immediately with the lowest amount of phosphate used (3\%). The residual F5 fractions increased to the sediment of all the other fractions. This clearly indicates that $\mathrm{Pb}$ ions are a privileged target for phosphates which can turn $\mathrm{Pb}$ into insoluble form without (F5) or with calcinations (F5c), reaching values between 80 and 92\%. Here, chemical and thermal treatments were both very effective, alone or combined, to stabilise $\mathrm{Pb}$.

Figure 9 (a) illustrates the distribution of species for $\mathrm{Cr}$. In the unamended sediment, $2.5 \%$ of $\mathrm{Cr}$ was in $\mathrm{F} 1$ and $\mathrm{F} 2,10.5 \%$ in $\mathrm{F} 3,19 \%$ in $\mathrm{F} 4$ and $68 \%$ in $\mathrm{F} 5$. Calcination alone yielded $10.8 \%$ in $\mathrm{F} 1,5.3 \%$ in $\mathrm{F} 2,5.7 \%$ in 
$\mathrm{F} 3,3 \%$ in $\mathrm{F} 4$ and $75.2 \%$ of $\mathrm{Cr}$ was insoluble (F5). This small increase of $\mathrm{Cr}$ in the most soluble fractions (F1 and F2) was due to the oxidation of $\mathrm{Cr}(\mathrm{III})$ to more soluble $\mathrm{Cr}(\mathrm{VI})$. After the treatment, there was a reduction in the quantity of $\mathrm{Cr}$ in the first four fractions to the profit of the residual fraction, which was proportional to the quantity of acid. The Fig. 9 (b) represents the concentration of $\mathrm{Cr}$ in the five fractions of a sediment treated with 5\% phosphate and calcined at various temperatures. Oxidation of $\mathrm{Cr}$ occurred, and $\mathrm{Cr}$ concentration rose from $4.1 \mathrm{mg} \mathrm{kg}^{-1}$ in fractions 1 and 2 to $22 \mathrm{mg} \mathrm{kg}^{-1}$ at $700^{\circ} \mathrm{C}$; however it may be noted that at temperatures of $1,100^{\circ} \mathrm{C}$, the solubility of chromium decreased and practically all of the metal was retained in the residual fraction.
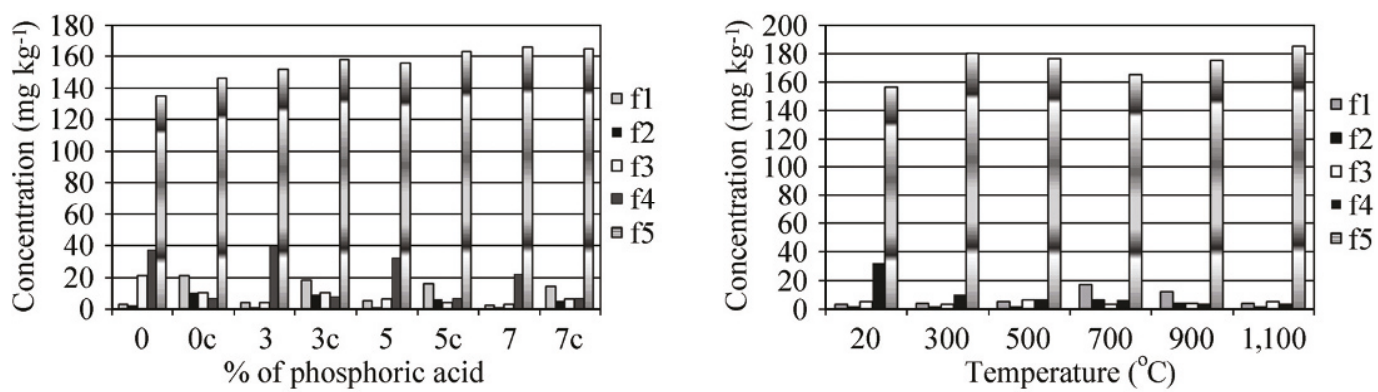

Fig. 9 Influence of quantity of acid on the speciation of $\mathrm{Cr}$ (a). Influence of calcination temperature on the speciation of $\mathrm{Cr}$ in a sediment treated with $5 \%$ phosphoric acid (b)

We also investigated the effect of phosphoric acid on Fe and Al speciation. Results are presented in Fig. 10. In the sediment, $\mathrm{Al}$ was present in the most stable F5 fraction and was undisturbed by the chemical or thermal treatment (97\% Al is considered as residual). Iron was also mostly in F5 (91,5\%) and F5c (93,5\%). With phosphoric acid treatment and calcinations, Fe was yet more insoluble ( $97 \%$ on average) in agreement with the known stability of iron oxides and phosphates. Similar results were derived for other metals.
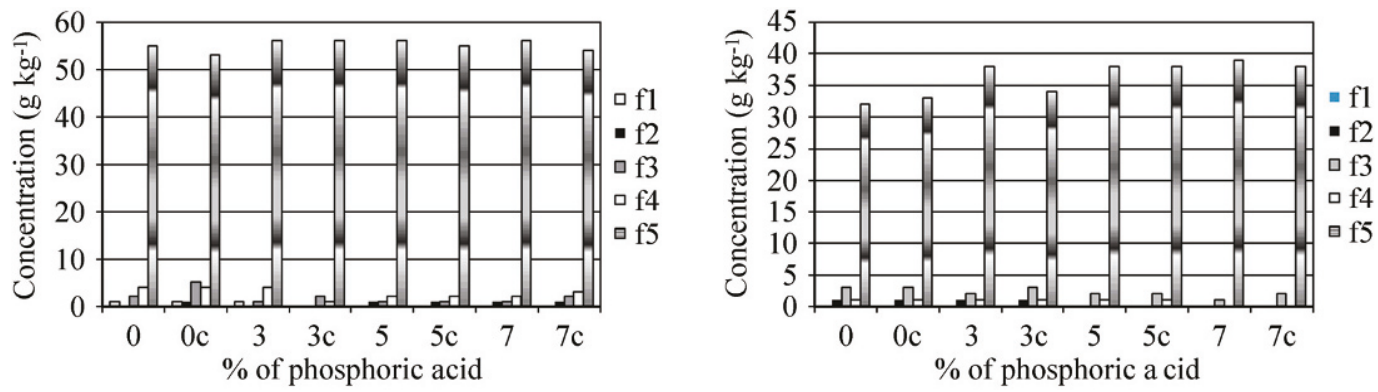

Fig. 10 Influence of quantity of acid and thermal treatment $\left(700^{\circ} \mathrm{C}\right)$ on the speciation of $\mathrm{Al}(\mathrm{a}$, left $)$ and $\mathrm{Fe}(\mathrm{b}$, right)

We conducted a standard Toxicity Characteristic Leaching procedure (TCLP) leaching test to obtain a global picture of the effects due to the treatment steps. Results for calcium and five heavy metals are given in Table 2. The resulting $\mathrm{pH}$ values of the TCLP test are also shown and confirm that phosphoric acid contributed to further acidification of the leaching medium. Remarkably, low levels of phosphoric acid (3\%) reduced heavy metal leaching to below the TCLP limit, at room temperature or following heating to $700^{\circ} \mathrm{C}$. The 7\% phosphoric acid treatment resulted in the lowest concentrations of mobile elements for all metals including $\mathrm{Ca}$.

\section{Conclusion}

This study has demonstrated that phosphoric acid treatment is an effective immobilization method for heavy metals in polluted sediments. Large scale industrial use of phosphoric acid would compete with use of phosphate as fertilizer, but this impact is small because $1 \%$ phosphoric acid is enough to treat the dredged sediments. Initially the acid causes the decomposition of carbonates and sulphides present in the 
dredged sediments. However, the acidity is compensated rapidly by the release of carbon dioxide and the formation of orthophosphate salts of calcium and other metals. Thermal treatment of the chemically treated sediments further enhances the stability of the newly formed minerals. The leaching of heavy metals is thus minimized. For beneficial reuse, treated sediments could be favourably compared to other natural materials. Further work is in progress to characterize the properties of other polluted sediments treated with phosphoric acid.

Table 2 Results of the toxic characteristic leaching procedure tests for the sediments. The percentages of added $85 \%$ phosphoric acid are indicated. Calcined sediments were heated to $700^{\circ} \mathrm{C}$. The numbers, except for $\mathrm{pH}$, represent concentrations in $\mathrm{mg} \mathrm{kg}^{-1}$

\begin{tabular}{|c|c|c|c|c|c|c|c|}
\hline & $\mathrm{Ca}$ & $\mathrm{Pb}$ & $\mathrm{Cd}$ & $\mathrm{Cr}$ & $\mathrm{Cu}$ & $\mathrm{Zn}$ & $\mathrm{pH}$ \\
\hline Untreated & 12,734 & 6.2 & 1.8 & 1.1 & 1.3 & 273 & 4.2 \\
\hline $3 \% \mathrm{H}_{3} \mathrm{PO}_{4}$ & 10,282 & 2.0 & 0.5 & 1.3 & 0.6 & 130.4 & 3.9 \\
\hline $7 \% \mathrm{H}_{3} \mathrm{PO}_{4}$ & 10,444 & 4.8 & 1.1 & 1.8 & 1.4 & 202.8 & 3.2 \\
\hline $\begin{array}{c}\text { Untreated } \\
\text { calcined }\end{array}$ & 14,560 & 6.0 & 0.5 & 12.5 & 1.6 & 38.2 & 4.1 \\
\hline $\begin{array}{c}3 \% \mathrm{H}_{3} \mathrm{PO}_{4} \\
\text { calcined }\end{array}$ & 7,756 & 2.4 & 0.4 & 5.5 & 1.4 & 74.6 & 3.9 \\
\hline $\begin{array}{c}7 \% \mathrm{H}_{3} \mathrm{PO}_{4} \\
\text { calcined }\end{array}$ & 2,654 & 3.8 & 0.1 & 0.9 & 1.8 & 35.4 & 3.5 \\
\hline TCLP limit & - & 5 & 1 & 5 & 5 & 250 & \\
\hline
\end{tabular}

\section{References}

Arnich N., Lanhers M-C., Laurensot F., Podor R., Montiel A., and Burnel D. 2003, In vitro and in vivo studies of lead immobilization by synthetic hydroxyapatite. Environmental Pollution, 124, pp. 139-149.

Basta N. T. and McGowen S. L. 2004, Evaluation of chemical immobilization treatments for reducing heavy metal transport in a smelter-contaminated soil. Environmental Pollution, 127, pp. 73-82.

Boisson J., Ruttens A., Mench M., and Vangronsveld J. 1999, Evaluation of hydroxyapatite as a metal immobilizing soil additive for the remediation of polluted soils. Part 1. Influence of hydroxyapatite on metal exchangeability in soil, plant growth and plant metal accumulation. Environmental Pollution, 104, pp. 225-233.

Bournonville B., Nzihou A., Sharrock P., and Depelsenaire G. 2004, Stabilisation of heavy metal containing dusts by reaction with phosphoric acid: Study of the reactivity of fly ash. Journal of Hazardous Materials, B116, pp. 65-74.

Bournonville B., Nzihou A., Sharrock P., and Depelsenaire G. 2006, Stabilisation of minerals by reaction with phosphoric acid: evolution of model compounds. Process Safety and Environmental Protection, 84, pp. 117-124.

Caetano M., Madureira M. J., and Vale C. 2003, Metal remobilisation during resuspension of anoxic contaminated sediment: Short-Term Laboratory Study. Water, Air and Soil Pollution, Vol. 143, No. 1-4, pp. 23-40.

Cao X., Ma L. Q., Rhue D. R., and Appel C. S. 2004, Mechanisms of lead, copper, and zinc retention by phosphate rock. Environmental Pollution, 131, pp. 435-444.

Chen D. C., He Z. L., Stoffella P. J., Yang X. E., Yu S., Yang J. Y., and Calvert D. V. 2006, Leaching potential of heavy metals $(\mathrm{Cd}, \mathrm{Ni}, \mathrm{Pb}, \mathrm{Cu}$ and $\mathrm{Zn}$ ) from acidic sandy soil amended with dolomite phosphate rock (DPR) fertilizer. Journal of Trace Elements in Medicine and Biology, 20, pp. 127-133.

Hettiarachchi G. M. and Pierzynsky G. M. 2006, Soil lead bioavailability and in situ remediation of lead-contaminated soils: a review. Environmental Progress, 23, pp. 78-93

Juracek K. E. and Ziegler A. C. 2009, Estimation of sediment sources using selected chemical tracers in the Perry lake basin, Kansas, USA. International Journal of Sediment Research, 24, pp. 108-125.

Li X. L. Wang G. H., Huang B. Y., Zhang, and Guo S. H. 2009, Adsorption of $\mathrm{Cu}$ and $\mathrm{Zn}$ onto $\mathrm{Mn} / \mathrm{Fe}$ oxides and organic materials in the extractable fractions of river surficial sediments. Soil and Sediment Contamination (Taylor \& Francis), Vol. 18, No. 1, pp. 87-101.

Loannidis T. A. and Zouboulis A. I. 2003, Detoxification of highly toxic lead-loaded industrial solid waste by stabilization using apatites. Journal of Hazardous Materials, B97, pp. 173-191.

Melamed R., Cao X., Chen M., and Ma L.Q. 2003, Field assessment of lead immobilization in contaminated soil after phosphate application. Science of the Total Environmental, 305, pp. 117-127.

Mulligan C. N., Yong R. N., and Gibbs B. F. 2001, An evaluation of technologies for the heavy metal remediation of dredged sediments. Journal of Hazardous Materials, 55, pp. 145-163.

McGowen S. L., Basta N. T., and Brown G. O. 2001, Use of diammonium phosphate to reduce heavy metal solubility and transport in smelter-contaminated soil. Journal of Environmental Quality-Abstroct, 30, pp. 493-500.

Piantone P., Bodenan F., Derie R., and Depelsenaire G. 2003, Monitoring the stabilization of municipal solid waste incineration fly ash by phosphation: mineralogical and balance approach. Waste Management, Vol. 23, pp. 225-243. 
Raicevic S., Kaludjerovic-Radoicic T., and Zouboulis A. I. 2005, In situ stabilization of toxic metals in polluted soils using phosphates: theoretical prediction and experimental verification. Journal of Hazardous Materials, B117, pp. 41-53.

Rulkens W. 2005, Introduction to the treatment of polluted sediments. Reviews in Environmental Science and Biotechnology, 4, pp. 213-221.

Stephens S. R., Alloway B. J., Parker A., Carter, J. E., and Hodson M. E. 2001, Changes in the leachability of metals from dredged canal sediments during drying and oxidation. Environmental Pollution 114, pp. 407-413.

Sugiyama S., Ichii T., Hayashi H., and Tomida T. 2002, Lead immobilization by non-apatite type calcium phosphates in aqueous solutions. Inorganic Chemistry Communications, 5, pp. 156-158.

Srinivasan M., Ferraris C., and White T. 2006, Cadmium and lead ion capture with three dimensionally ordered macroporous hydroxyapatite. Environmental Science and Technology, Vol. 40, No. 22, pp. 7054-7059.

Tessier A., Campbell P. G. C., and Blasson M. 1979, Sequential extraction procedure for the speciation of particulate trace metals. Analytical Chemistry, 51, pp. 844-850.

Theodoratos P., Papassiopi N., and Xenidis A. 2002, Evaluation of monobasic calcium phosphate for the immobilization of heavy metal in contaminated soils from Laviron. Journal of Hazardous Materials, B94, pp. $135-146$.

Zwonitzer J. C., Pierzynski M., Ganga M., and Hettiarachchi G. M. 2003, Effects of phosphorus additions on lead, cadmium, and zinc bioavailabilities in a metal-contaminated soil. Water, Air and Soil Pollution, Vol. 3, No. 1-4, pp. 93-209. 